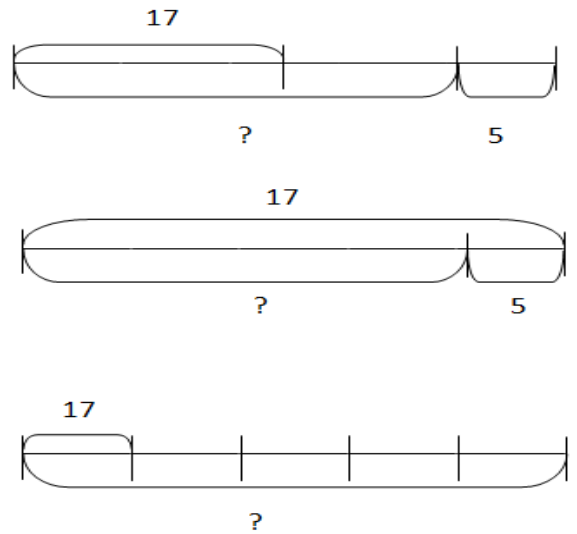

Анализ опыта учителей начальных классов позволяет сделать вывод о том, что на уроках используются разнообразные виды заданий, способствующих развитию у младших школьников вариативности мышления, например, геометрические ребусы, кроссворды, игры «Верю - не верю», «Внимание» и другие, решение частичнопоисковых задач, задания на выявление закономерностей, распределение объектов на группы, отыскание ошибок...

Творческая деятельность должна стать неотъемлемой частью образовательного процесса школьников. Выполняя творческие задания, дети находятся в такой ситуации, что, создавая что-либо новое, они получают новые знания самостоятельно, это способствует лучшему усвоению и запоминанию этой информации.

$$
* * *
$$

1. Активные методы обучения и воспитания: психолого-педагогический тренинг креативности: Методические указания / Сост. М. М. Кашапов. Яросл. гос. ун-т. Ярославль, 2001. 39 с.

2. Бантова М. А. Методика преподавания математики в начальных классах. Москва : Просвещение, 1984. C. 239-241.

3. Богоявленская Д. Б. Интеллектуальная активность как проблема творчества. Москва: Интелл, 2015. $274 \mathrm{c}$.

4. Виноградова Л. В. Развитие мышления учащихся при обучении математике. Петрозаводск : Карелия, 1989. 175 с.

5. Дружинин В. Н. Психология общих способностей : учебное пособие. 3-е издание. СанктПетербург : Питер, 2007. 368 c.

6. Истомина Н. Б. Активизация учащихся на уроках математики в начальных классах. Москва : Просвещение, 1985. 63 с.

7. Лернер И. Я. Развивающее обучение с дидактических позиций // Педагогика. 1996. № 2. С. 7-11.

8. Пономарев Я. А. Психология творчества и педагогика. Москва : Наука, 1976. С. 76-91.

\title{
Соколова Л.А. \\ Развитие эмоционального интеллекта у подростков в условиях тематических смен: результаты эмпирического исследования
}

ФГБОУ ВО «Костромской государственный университет» (Россия, Кострома)

doi: $10.18411 / l j-07-2021-154$

Аннотация

В статье рассматриваются особенности развития эмоционального интеллекта у подростков в условиях тематических смен. Проанализированы результаты эмпирического исследования развития эмоционального интеллекта у подростков.

Ключевые слова: подростковый возраст, эмоциональный интеллект, тематическая смена. 


\section{Abstract}

The article discusses the features of the development of emotional intelligence in adolescents in the context of thematic shifts. The results of an empirical study of the development of emotional intelligence in adolescents are analyzed.

Keywords: adolescence, emotional intelligence, thematic shift.

Подростковый возраст является значимым для развития эмоциональной сферы человека, так как в этот возрасте у подростков большая возбудимость, возникают переживания по отношению к различным ситуациям, развитое чувство принадлежности к группе, предъявление высоких требований к дружбе, в основе которой лежит общность интересов. Этот возраст считается особенно эмоционально насыщенным, неустойчивым, неуправляемым, следовательно, очень важно уметь распознавать, контролировать и управлять своими эмоциями и эмоциями других людей [1].

Многие подростки очень активные, участвуют в различных объединениях, мероприятиях, тематических сменах. Тематические смены в загородных детских лагерях являются особенным пространством, наполненными эмоциональными событиями. Тематические смены отличаются от других смен тем, что у них есть определенная тематика, логика мероприятий, которые отличаются своей направленностью и насыщенностью событий. В каждой смене свое содержание, свои события. Участники смены могут их воспринимать по-разному, при этом испытывать разные эмоции.

Для исследования уровня развития эмоционального интеллекта у подростков нами было проведено эмпирическое исследование, в котором приняли участие 15 учащихся в возрасте 11-16 лет. Выборку составили участники тематических смен лагеря. Исследование проводилось в ноябре 2020 года. Участники проходили тестирование в электронном виде с помощью платформы для создания опросов Google.

Испытуемым предъявлялись две методики: методика оценки «Эмоционального интеллекта» (опросник EQ) Н. Холла; опросник эмоционального интеллекта «ЭмИн» Д. В. Люсина.

В ходе эмпирического исследования были выявлены компоненты эмоционального интеллекта по методике оценки «Эмоционального интеллекта» (опросник EQ) Н. Холла: эмоциональная осведомленность, управление своими эмоциями, самомотивация, эмпатия, распознавание эмоций других людей. Методика состоит из 30 утверждений, каждое из которых испытуемый должен оценить по одной из 6 шкал, от $(-3)$ «Полностью не согласен», до (+3) «Полностью согласен».

Также были выявлены компоненты эмоционального интеллекта по опроснику эмоционального интеллекта «ЭмИн» Д. В. Люсина: межличностный интеллект, внутриличностный интеллект. Опросник состоит из 46 утверждений, каждое из которых испытуемый должен оценить по одной из 4 шкал, от (1) «Совсем не согласен», до (4) «Полностью согласен».

В исследовании были раскрыты специфические характеристики эмоционального интеллекта по методике оценки «Эмоционального интеллекта» (опросник EQ) С. Холла.

По шкале «Эмоциональная осведомленность» (представления об эмоциях и их проявлениях) низкий уровень выявлен у (13\%) испытуемых, средний уровень у (54 \%), высокий уровень выявлен у (33 \%). Это говорит о том, что большая часть исследуемых подростков осознает свои эмоции и чувства, а также причины их возникновения.

По шкале «Управление своими эмоциями» (скорее это эмоциональная отходчивость, эмоциональная неригидность) низкий уровень выявлен у (67\%) испытуемых, средний уровень у $(27 \%)$, высокий уровень выявлен у (6 \%). Таким образом, большая часть испытуемых с трудом может справиться со своими 
негативными эмоциями, переживает их длительное время, что может привести к конфликтам, обидам и непониманию с окружающими.

По шкале «Самомотивация» (произвольное управление своими эмоциями) низкий уровень выявлен у (47\%) испытуемых, средний уровень у (26 \%) и высокий уровень выявлен у $(27 \%)$. Это говорит о том, что большая часть подростков умеют управлять своими эмоциями.

По шкале «Эмпатия» (способность сопереживать другим, воспринимать их эмоции, понимать их) низкий уровень выявлен у (40\%) испытуемых, средний уровень у $(20 \%)$, высокий уровень эмпатии выявлен у (40\%). Большая часть испытуемых понимает эмоции других людей, сопереживает окружающим, проявляет заботу и внимание, готова оказывать поддержку.

По шкале «Распознавание эмоций других людей» (в том числе, умение воздействовать на эмоциональное состояние других людей) низкий уровень выявлен у (54 \%) испытуемых, средний уровень у (33 \%), высокий уровень выявлен у (13\%). Это говорит о том, что большая часть подростков не способна влиять на эмоциональное состояние других учащихся, не владеет навыками убеждения, не умеет создавать положительный эмоциональный настрой в коллективе.

Рассмотрим специфические характеристики по опроснику эмоционального интеллекта «ЭмИн» Д. В. Люсина.

По межличностному эмоциональному интеллекту (что предполагает оценку понимания и управления чужими эмоциями) низкие показатели у (23 \%) испытуемых, средние - у (23 \%) испытуемых, высокие значения выявлены у (54 \%) испытуемых. Это говорит о том, что большая часть подростков способна понимать переживания других людей.

По внутриличностному эмоциональному интеллекту (включает понимание, управление и выражение собственных эмоций) низкие значения выявлены у (46\%) испытуемых, средние - у (8 \%), высокие значения обнаружены у (46\%) испытуемых. Это говорит о том, что большая часть испытуемых способна распознавать собственные эмоции, понимать и управлять ими в необходимых случаях.

Таким образом, тест «Эмоционального интеллекта» С. Холла показывает, что большинство респондентов (более 60\%) осознает свои эмоции и чувства, а также причины их возникновения; понимает эмоции других людей и сопереживает им. Более половины подростков (54\%) показало способность к произвольному управлению своими эмоциями на основе самомотивации. При этом многие респонденты $(67 \%)$ с трудом могут справиться со своими негативными эмоциями, переживают их длительное время, прикладывают существенные усилия для регуляции своего поведения. Другой трудностью для респондентов (низкий уровень выявлен у $54 \%$ испытуемых) является воздействие на эмоциональное состояние других людей. Опросник эмоционального интеллекта «ЭмИн» Д. В. Люсина показывает схожие значения.

Таким образом, мы можем зафиксировать, что задачи развития эмоционального интеллекта в подростковом возрасте должны рассматриваться педагогами как актуальные. Такая работа может осуществляться, в том числе, в условиях летних смен, где подростки оказываются в ситуации интенсивного взаимодействия с другими детьми и взрослыми. Особое внимание следует обращать на спонтанные переживания подростков и развитие эмоциональной отходчивости, а также на освоение подростками способов эмоциональной поддержки по отношению к другим людям.

$$
* * *
$$

1. Кочубей Б. И. Эмоциональная устойчивость школьника / Б. И. Кочубей, Е. В. Новикова. - Москва : Знание, 2012. -80 c. 